\title{
METHODOLOGICAL FEATURES OF THE TRAINING OF A FUTURE PRIMARY SCHOOL TEACHER FOR ORGANIZING CHILDREN'S LEISURE ACTIVITIES
}

\section{Olha Honcharuk}

Ph.D. in Pedagogy, Associate Professor, Senior Lecturer at the Department of Theory and Methods of Primary School, Lesya Ukrainka Volyn National University, Ukraine e-mail: Olga18092006@gmail.com,orcid.org/0000-0001-8463-7401

\section{Andrii Galaidin}

Ph.D. student, Polonia University in Czestochowa, Interdisciplinary Faculty, Poland e-mail: a.galaidin@ap.edu.pl,orcid.org/0000-0002-5236-1495

\section{Summary}

The article has analyzed and covered methodological features of the training of a future primary school teacher for organizing schoolchildren's leisure.

The aim of the article is to substantiate the principal methodological features of efficient training of future primary school teachers for organizing children's leisure activities. The aim has been implemented through solving the following tasks: 1) to show a need to take into account the age and individual characteristics of primary school children in the system of professional training of a teacher; 2) to justify special aspects of children's leisure by marking its specific kinds and types as well as the principles of high-performance organization.

In order to achieve the purpose and to complete the tasks, the author has used the methods of analysis, synthesis, induction, deduction, generalization and systematization.

It is emphasized that the training system of a future primary school teacher for organizing leisure of a child as its subject should comply with general task-age features of the development, content, dynamics and progress of which has its specifics. A primary school child is considered not as a passive object of leisure activities but as their subject, a creator realizing his preferences and satisfying his interests.

The main methodological features of the system of training of a future primary school teacher for organizing pupils' leisure are defined as follows: consideration of the age and individual peculiarities of schoolchildren, specifics of children's leisure when organizing leisure activities for junior schoolchildren, students' mastery of competencies to involve children into those kinds, types and forms of leisure activities which facilitate the development of a creative potential of an individual, his drive for self-development, self-improvement and self-esteem in a micro-environment and society. Based on the defined criteria features, the author has established forms, types and principles of the leisure activities of primary school children.

Keywords: children's leisure, leisure activities, methodological features, training system, future teachers, knowledge-age approach. 


\section{Introduction}

A task of the modern school, especially of its basic unit, is to train a future citizen and worker, who realizes his social responsibility, is a subject of the personal and professional growth, embraces various types of creative activities. In this regard, a pride of place goes to the development of schoolchildren's skills to organize their spare time efficiently because it provides the most favorable conditions for recreational processes, which relieve intensive physical, intellectual, mental loads of a person. In light of the before mentioned, an essential component of the professional training of a future primary school teacher for organizing leisure activities of junior schoolchildren is his methodological background in the organization of children's leisure which in turn should cover the specifics of those sort of activities (their kinds, forms, types) and requirements for their organization in terms of primary-school age.

Analyzing the issue of professional becoming of a future primary school teacher, O. Abdulina, V. Bondar, O. Dubaseniuk, O. Budnik, P. Husak, L. Koval, O. Komar, I. Osadchenko, R. Prima, O. Savchenko et al., primarily examine it from the standpoint of professional training. K. Avramenko, N. Hrytsai, O. Mitina, V. Motorina, S. K. Tkachenko et al. have studied a methodological component of the professional training of future teachers. Methodological features of the training of future primary school teachers have been analyzed by T. Amelchenko, N. Maksymenko, N. Cherviakova, I. Upatova, who cover the essence and conditions of successful implementation of the methodological training of students, specify its options in the educational process. In this research, the author focuses on the methodological provisions which should be kept in mind during the training of future primary school teachers for an efficient organization of children's leisure.

The article aims to substantiate the main methodological features of effective training of future primary school teachers for organizing children's leisure. The aim has been implemented through solving the following tasks: 1 ) to show a need to take into account the age and individual characteristics of primary school children in the system of professional training of a teacher; 2) to justify special aspects of children's leisure by marking its specific kinds and types as well as the principles of effective organization.

In order to achieve the purpose and to complete the tasks, the author has used the methods of analysis, synthesis, induction, deduction, generalization and systematization.

\section{Research results}

While training future primary school teachers for organizing children's leisure, the author has had regard to the provisions stating that pupils' leisure is characterized by the specific features, among which are such priorities as freedom and justification of this type of activities, focus on meeting needs, interests and preferences of an individual; a drive to join different forms of work having modern names, content, plot etc. In the context of this research, the author has considered a schoolchild not as a passive object of leisure activities but as its subject, a creator realizing his preferences and satisfying his interests. Thus, the task-age approach (L. Vakhovskyi, M. Mykhailenko, O. Piesotska, S. Kharchenko et al.) has been determined as a methodological basis of the system of the training of a future primary school teacher for developing a primary school child as a subject of leisure activities. The essence of the approach has been expressed through the following generalized provisions:

- at every stage of the life course, a person faces a range of tasks, the exercise of which influences his/her personal development; 
- education should be based bearing in mind a favorable solution of these tasks at every stage of a person's life;

- individual nature of a person's education having the task-age approach in mind provides for rendering concrete assistance to him/her for solving the problems he/she faces (Dowell, 1997). In view of the above, the author believes the whole system of the training of a future primary school teacher for organizing leisure activities of a child as its subject should comply with general task-age features of the development, content, dynamics and progress of which has its specifics under the framework of individual life of a primary school child.

The author has identified the first methodological feature of the training of a future primary school teacher for organizing a child's leisure as the consideration of age and individual peculiarities of primary school children in the system of professional training of the teacher. In this context, its fundamentals involve taking into account the following in terms of the organization and realization of leisure activities of junior schoolchildren:

- changes in physical and psychophysiological development which allow a pupil to join all types of activities;

- psychological new formations which characterize the most significant achievements in the personal growth and are a basis of a child's development at the next age stage (arbitrariness as a specific characteristic of mental processes and their internal mediation which is manifested in the ability to deliberately set targets, search for and find means of their accomplishment, overcome the difficulties and obstacles; an internal road map because in the process of exercising leisure tasks, school children look for the best ways of their solution, choose and compare alternatives, plan a procedure and means of their implementation;

- intensive physical activity, emotionality, children engagement, their failure to focus attention for a great deal of time. In this regard, leisure activities should be short (up to 1 hour), and it makes sense to introduce peaceful games, musical interludes, cartoon collections etc. every $10-15$ minutes;

- quick exhaustion and tiredness of primary school children due to the abundance of interaction, impressions, emotions, intense activities;

- changes of a social situation of a child's development which is often characterized by a challenging adjustment to it;

- a need of a teacher's emotional support of actions, conduct of schoolchildren as well as the use of credits, encouragement, justification of success, which make schoolchildren satisfied, happy, confident etc.

- socio-psychological age tasks of primary school age (development of reflection on own activities; coping with the contradictions between the roles of a child and schoolchild ( 6 years crisis) and between the striving to improvisation, creativity, democratic communication and a propensity for stereotypes, subordination to authorities);

- peculiarities of the socialization of primary school children (active integration of a child into a new school environment; consolidation of the role of the child as a subject of socialization, relative independence in terms of the choice of values, ideals, social environment, types of activities; dominance of the influence of a new social environment (a class, an interest group).

With reference to the above, to organize effective leisure activities of primary school children, it is essential to form moral qualities of their subjects (mutual respect, mutual assistance and help, sociability, kindness, responsibility etc.) through vivid emotional events and contribute to the development of creative skills, thinking, curiosity, thoughtfulness, observation skills of school children; to broaden their outlook as well as leisure interests, cultural needs 
of children; to inculcate resolute qualities (insistence, leadership, responsibility, self-mastery, discipline etc.) (Iakovleva, 2014: 23).

The following methodological feature of the system of professional training of a future primary school teacher is the consideration of specifics of child leisure while organizing leisure activities of children. In this context, accepting N. Krasnova's view, the author has defined child leisure as fundamental which is:

- a source of self-realization and an extreme activation of creative activity, emotionally tinged; it adds emotional feelings to every form of activities;

- a school preventing soullessness, emotional poverty, blinkered vision, practice restraint, but not only preventing delinquent acts;

- a school of support, encouragement of any child, much less a weak, "difficult" child;

- a sphere of self-education, that personal space which most fully and expressively covers a child's natural needs of freedom, independence, self-expression and self-development (Krasnova).

According to N. Krasnova, in the area of child leisure, the hierarchy and purpose are constantly changing. It influences the choice of leisure activities of a child and their content. Thus, N. Krasnova conditionally divides children's' leisure activities into the following groups:

1) associated with the function of a child's recreation (fresh air and exercise, sports, offevenings, games, amusements and entertainment etc.);

2) related to the advancement of erudition, use of spiritual values (reading, watching of films and broadcasts, visiting exhibitions, museums, travelling etc.);

3 ) one which promotes the development of spiritual strengths, active creative activity (labor, technical, sporting and playing, artistic-stage, research, applied);

4) one which realizes the need of communication (activities in a club, hobby group, creative association, reunion, discos, festivals, forums, social dances etc.);

5) associated with intentional creative activities of children (camps, auditions, competitions, holiday associations, walking tours, active schools etc.) (Krasnova).

As a part of the study, the author has also found out that a key feature of children's leisure is its game-based component. Thus, H. Khrypkova highlights children of this age are characterized by activity, flexibility, emotionality, fast response, focus on entertainment and game-related activities, aesthetic attitude to the world around them, kindness, amicability, and a tendency to take example by an authority (Khrypkova, 1988). Therefore, N. Flehontova stresses a playing essence of leisure activities (autotelic and inherently valued) as their natural characteristics is scientifically grounded by the fact that a game is an integral and specific type of cultural activity in which an individual acts as free from life challenges and can be a creative subject indisposed to a particular coercion. By coinciding with the compensative function in some terms, a game becomes a distinctive form of the cultural activities which affects different aspects of the social regulation (Flehontova, 2007).

Increasing the role of playing leisure, B. Ierasov identifies its significant characteristics such as a movement in space and time, separation from other spheres, existence outside everyday life. "A game" - he marks - requires abstracting participants from everyday life, production activities, and standard social environment. It takes place inside the personal limits meeting the relevant rules. It is not associated with material interests by itself - it is impersonal" (Ierasov, 1996). Based on the above, one can sum up that organization of leisure activities of junior schoolchildren should be game-oriented.

Thus, in I. Boichev's opinion, the specifics of the organization of child leisure are stipulated by the features of its object (who is also a subject of free choice of content, forms 
and kinds of leisure) - a junior schoolchild, a nature of leisure interaction (a high level of psychological compatibility, sympathetic understanding and respect; empathy; inadmissibility of peremptory command intonation) with a teacher (as a carrier of sociocultural experience and a mediator between a child and culture, i.e. a subject of pedagogical support and proxy guiding), content ("building material" for a pedagogical projecting and schoolchildren's acquisition) and means of a pedagogical influence (forms, methods, techniques) (Boichev, 2005).

Following the analysis of the psychological and pedagogical literature and personal education experience, the author has marked that a leisure of junior schoolchildren has a complex double nature: on the one hand, this is a free, voluntary creative activity which is natural and often spontaneous and, on the other hand, this activity is learning, educative, culture-formed and organized and managed by teachers.

Taking into account the above, leisure of junior schoolchildren is deemed as a child's activity in his spare time meeting the personal interests or preferences and which favors for him and makes it possible to manifest himself as a personality - a subject of this activity.

Another methodological feature of the system of training of a teacher for organizing schoolchildren's leisure is his mastery of competencies to involve children in those types and kinds of leisure activities which allow developing a creative potential of a personality, his aspiration for the personal growth, self-perfection and self-esteem in a micro-community and society.

In the process of scientific inquiry, the author has emphasized that nowadays, there is a lack of a unified scientific vision of types and kinds of leisure and leisure activities of a person in general and children's leisure in particular. In the author's opinion, such a dispersive and ambiguous definition of kinds and types of leisure activities, their identification or equivocation slow a search for efficient methods of solution of the problem under study.

The author has proposed to classify types and kinds of leisure activities of junior schoolchildren (fig. 1 and 2) following well-defined criteria (Honcharuk, 2018):

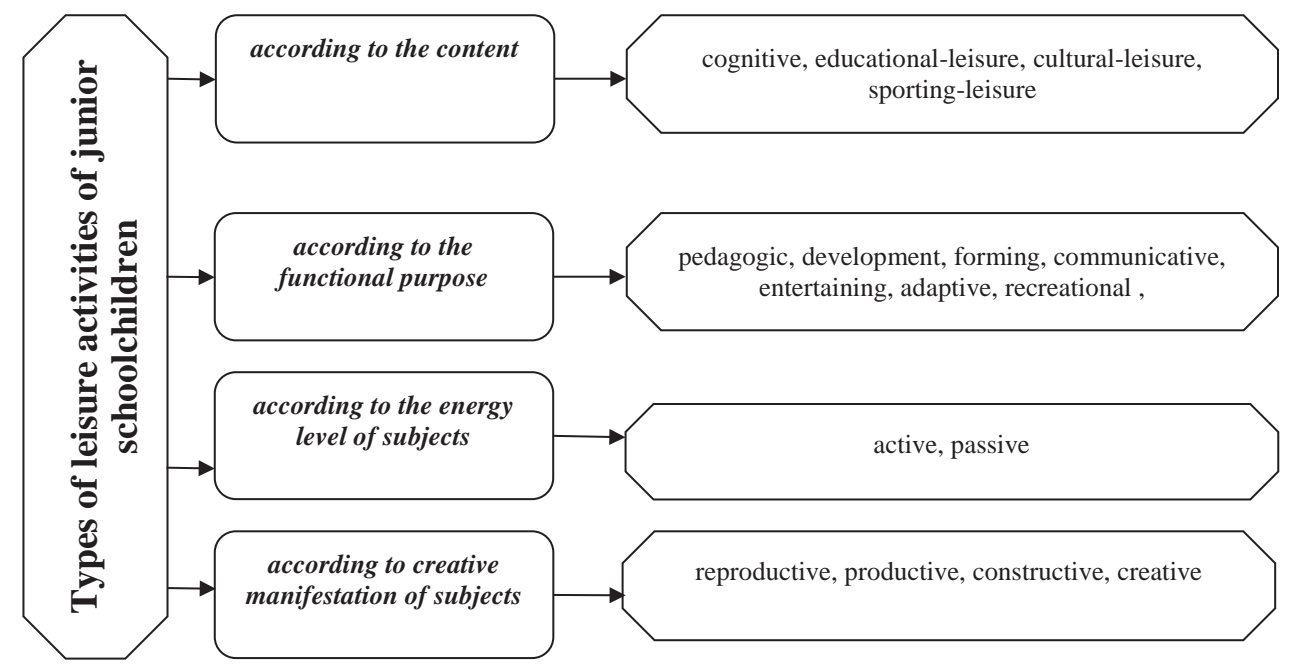

Fig. 1. Classification of the types of leisure activities of junior schoolchildren 
Thus, as can be seen from figure 1, to classify the types of leisure activities of junior schoolchildren, the author has used the following criteria features: a content of activities, functional purpose of activities, levels of energy and creativity of its subjects.

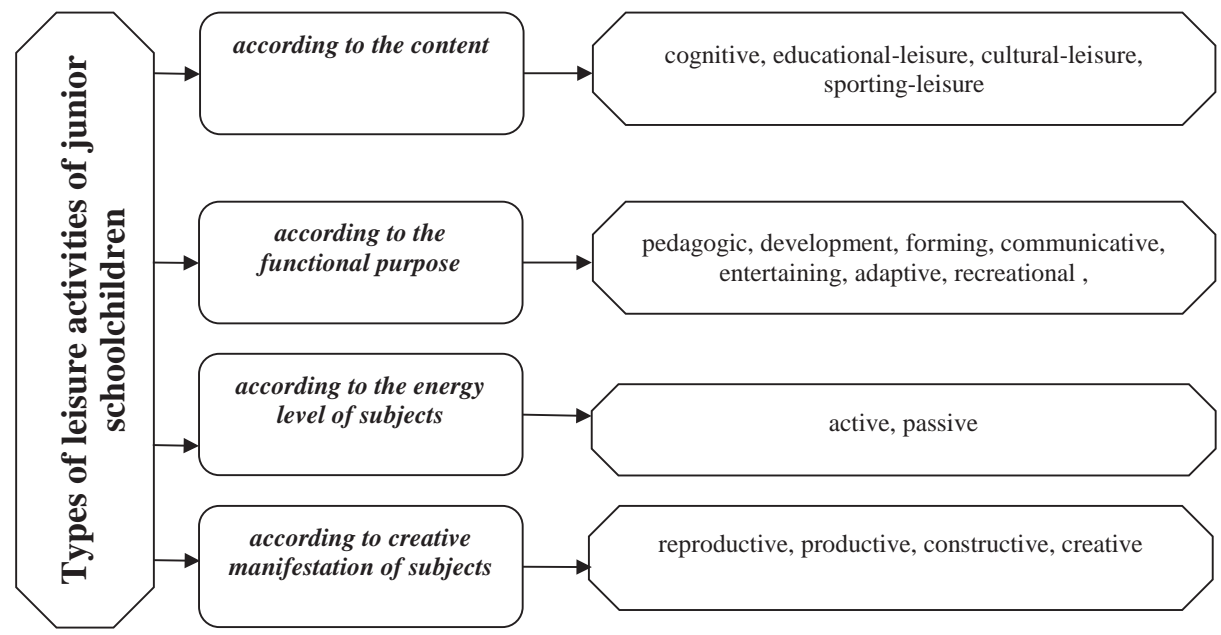

Fig. 2. Types of leisure activities of junior schoolchildren

Therefore, figure 2 shows that to determine a type of leisure activities of primary school children, the author has offered to use such criteria as a clear goal-setting; organization level of activities, their control; term and frequency of activities.

The author believes the availability of a well-defined classification and principles is essential when studying the problems of the system of the training of future teachers for organizing leisure activities of junior schoolchildren.

By combining different approaches (N. Volkova, A. Volovyk, V. Volovyk, O. Demchenko, I. Zvierieva, A. Kapska, N. Flehontova et al.) to the classification of the forms of leisure activities, the author has determined the criteria and thus, forms of their implementation for primary school children (fig. 3) (Honcharuk, 2018).

Consequently, analysis findings of fig. 3 confirm that forms of leisure activities are classified as follows: according to the number of participants, form and method of activities, a specific aim and organization complexity.

The evaluation of the psychological and pedagogical literature proves that productivity and effectiveness of the forms of leisure activities of primary school children depend on suitable methods of the achievement of a particular aim, ways of involving children into its accomplishment, well-managed compliance with the principles of their realization by an organizer.

Based on a scientific inquiry, organization principles of leisure activities are regarded by the author as the observance of requirements which ensure the effectiveness and outcome of the organization of leisure activities for junior schoolchildren.

Summarizing the scientific views on the principles of leisure activities, the author has defined such (fig. 4) which act as a methodological ground of the system of professional training of future primary school teachers for organizing pupils' leisure (Honcharuk, 2018). 


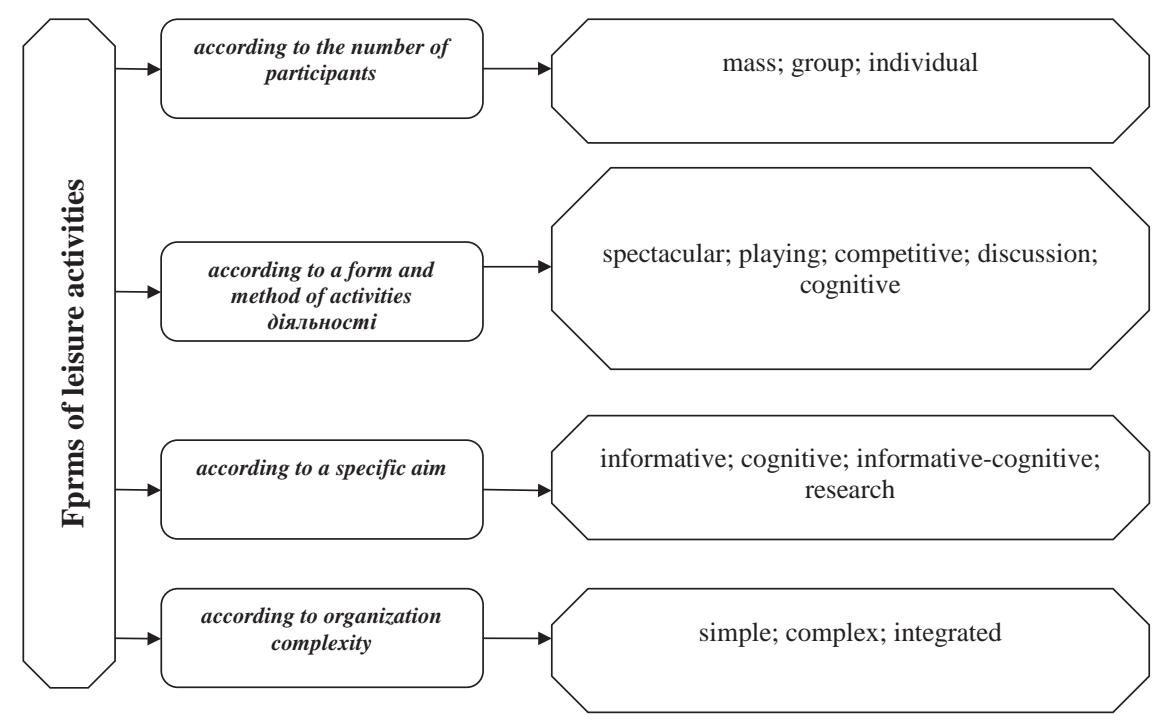

Fig. 3. Classification of the forms of leisure activities of primary school children

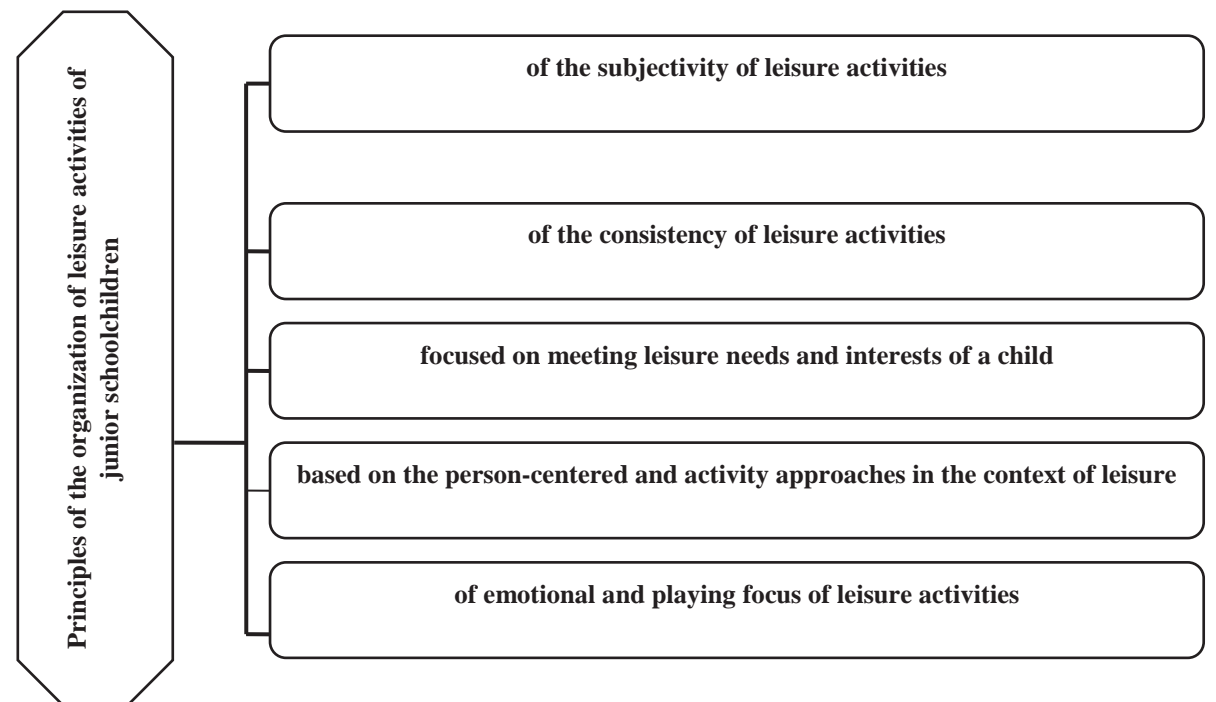

Fig. 4. Principles of the organization of leisure activities for junior schoolchildren

Following fig. 4, the author believes the principles of subjectivity, focus on meeting leisure needs and interests of a child, of consistency of leisure activities, based on the personcentered and activity approaches in the context of leisure, of emotional and playing orientation are fundamental for organizing leisure activities. 


\section{Conclusions}

Consequently, research findings make it possible to sum up that leisure activities of junior schoolchildren have a complex, double nature, because these activities are voluntary, natural, creative as well as developmental, educative, culture-formed and organized and managed by teachers.

The author has interpreted leisure of junior schoolchildren as a child's activity in his spare time meeting the personal interests or preferences and one which favors for him and makes it possible to manifest himself as a personality - a subject of this activity. Methodological features of the training of future primary school teachers for organizing children's leisure include keeping in mind of age and individual peculiarities of schoolchildren when organizing leisure activities, specifics of child leisure, students' mastery of competencies to involve children in those types and kinds of leisure activities which permit developing a creative potential of a personality, his aspiration for the personal growth, self-perfection and self-esteem.

\section{References}

Boichev I. I. (2005) Pidhotovka maibutnoho vchytelia do orhanizatsii kulturno-dozvillievoi diialnosti uchniv [Training of a future teacher for organizing cultural and leisure activities for children] (PhD Thesis).

Honcharuk O. V. (2018) Orhanizatsiia dozvillievoi diialnosti molodshykh shkoliariv: navch.metod.posib [Organization of leisure activities of junior schoolchildren]. Lutsk. Vezha-Druk. [in Ukrainian]

Dowell M. (1997) Orientirovannaya na reshenie zadachi sotsialnaya rabota [Social work oriented towards solving tasks]. Kiev. [in Russian]

Erasov B. S. (1996) Sotsial'naya kul'turologiya: Posobie dlya studentov vysshikh uchebnykh zavedeniy. 2-e izd., ispr. i dop. [Social culture studies. A textbook for students of higher education institutions: $2^{\text {nd }}$ revised and corrected ed.]. M.: Aspekt Press. [in Russian]

Krasnova N. P. Tekhnolohii orhanizatsii dozvillia u sotsialnopedahohichnii roboti [Technologies of the organization of leisure activities in the context of socio-pedagogical work]. Retrieved from: http://www.rusnauka.com/29_SSN_2013/Pedagogica/6_145632.doc. htm

G. Khripkova (ed.) (1988)Мир детства. Младший школьник. [The world of childhood. A schoolchild]. Moscow: Москва: Pedagogika. [in Russian]

Flehontova N. M. (2007) Pedahohichna orhanizatsiia kulturnoho dozvillia shkoliariv : navch.metod. posib. [Pedagogical organization of the cultural activities of pupils: a study guide]. Kyiv: Osvita Ukrainy. [in Ukrainian]

Iakovleva O. V. (2014) Molodshyi shkoliar yak subiekt sotsialnoho vykhovannia [A schoolchild as a subject of the social education]. Sotsialna pedahohika: teoriia ta praktyka, no. 1, p. 23. 